\title{
Multicentre Management of Prostate Cancer in Mali
}

\author{
Alkadri Diarra, Fousseini Sissoko, Mahamat Ali, Amadou Kassogué, Honoré Berthé \\ Mamoutou Keita, Zanafon Ouattara \\ Chirurgien Urologue, CHU Luxembourg of Bamako, Mali. \\ *Corresponding Author: Alkadri Diarra, Chirurgien Urologue, CHU Luxembourg of Bamako, Mali.
}

\section{Abstract}

Introduction: Prostate cancer has become the most frequent cancer in men and the second leading cause of cancer deaths after lung cancer. The objective of this study was to describe the epidemiological and therapeutic aspects of prostate cancer from the urology departments of the four (4) University Teaching Hospitals (UTHs) in Mali.

Patients and Methods: This was a multicentre prospective study carried out in the four University Teaching Hospitals in Mali. These were University Teaching Hospitals with a urology department, and these correspond to all the urology departments located within Bamako, the capital of Mali. The study was carried out over a period of 6 months (from January to June 2018) on the cases of prostate cancer confirmed on histopathology. We have developed a survey sheet validated by all of the departments which made it possible to collect data during the study period.

Results: A total of 52 cases of prostate cancer ie 54.9\% was referred to us by health personnel. The PSA was $>100 \mathrm{ng} / \mathrm{ml}$ in 24 patients ie $46.15 \mathrm{ng} / \mathrm{ml}$ and represented the most frequent presenting complaint with $34.61 \%$, giving a mean of $139.58 \mathrm{ng} / \mathrm{ml}$ and a standard deviation of 167.527 .

$86.52 \%$ of patients had hormone therapy ; 2 underwent radical prostatectomy ie $3.84 \% .34 .6 \%$ and $32.7 \%$ of patients were respectively managed at Point $G$ and Luxembourg University Teaching Hospitals.

Conclusion: This is the first multicentre study on prostate cancer in Mali and the patients were diagnosed late. Hormone therapy was the mostly used treatment modality, considering the lack of screening and management of localised forms by urologists.

Keywords: Prostate cancer, multicentre, Mali

\section{INTRODUCTION}

Prostate Cancer has become the most frequent cancer in men and the second leading cause of cancer mortality after lung cancer. The early diagnosis and subsequent treatment of prostate cancer has witnessed new changes in the last twenty years. Presently, the diagnosis of prostate cancer is based on serum PSA, findings on digital rectal examination (DRE) and prostate biopsies. Prostate biopsy is not only a key investigation in the diagnosis of prostate cancer, butalso, an important element in its therapeutic management.
Age, past history of prostate cancer, and ethnicity of patient have been reported as the major risk factors [1]. However, the role of genetic, hormonal and environmental factors has been strongly recognised. Also, in our region, this cancer is characterised by late diagnosis at a locally advanced or metastatic stage $[2,3]$.

Current evidence shows that prostate cancer affects and is still killing thousands of patients despite enormous progress made by modern medicine, which is still yet to find a true curative treatment for this cancer. 
In Mali, no reliable data on prostate cancer exists based on histopathology; this has not been helped by difficulties in research collaboration between different departments.

The objective of this multicentre survey was to carry out a prospective, descriptive study on the epidemiological and therapeutic aspects of prostate cancer in the urology departments of the 4 University Teaching Hospitals in Mali.

\section{Patients And Methods}

This was a multicentre prospective, descriptive study carried out in the four university departments of urology in Mali, all within Bamako. These urology departments are found in the following University Teaching Hospitals: Point G, Gabriel Toure, Kati and Luxembourg. A chechlist validated by all the departments was first established which was used to collect data during the study period. The main elements in the checklist is the management of prostate cancer. The studyspanned a period of 6 months, from January to June 2018 on cases of histopathologically confirmed prostate cancer.

The specimens were fixed with $10 \%$ formol included in Paraffin; staining was done with haematoxylin eosine and read under low power then high power microscope. The data was entered in a computer and analysed using SPSS version 2.0 and Word 2016 softwares.

\section{RESULTS}

During the period 3840 patients were admitted at the 4 departments. A total of 52 cases of histopathologically confirmed prostate cancer was studied;29(55.8\%) were referred to us by other health personneland the remaining 23 (44.2\%) were self-referrals. The patients managed by each hospitals are in table1.
Only one $(1.9 \%)$ patient had a known past family history of prostate cancer; 12 (23.1\%) had no family history while the remaining 39 (75\%) did not know whether there was any family history or not.

The average age of our patients was 71 years old. Patients from Bamako were the most represented with a rate of $61.5 \%$. Urinary bilharziasis marked the urological history, i.e. $82.7 \%$ and $1.9 \%$ with cancer prostate history in their family.

The liberal sector was the most represented with a rate of $46.2 \%$ followed by the civil servant sector $38.8 \%$. The most represented patients were out of school with a rate of $50 \%$.

PSA was $>100 \mathrm{ng} / \mathrm{ml}$ in 24 (46.2\%) patients and was the most frequent presenting complaint with a mean of $139.58(S D 167.53) \mathrm{ng} / \mathrm{ml}$ (see figure 1).

Clinical symptoms were most commonlyurinary frequency and dysuria occurring in 12(23.07\%) and 8 (15.4\%) patients respectively. (see table 2 ).

DRE was an essential part of the physical examination; and revealed pelvic wall involvement in 22 (42.3\%) and a nodular prostate in 30 (57.7\%). Prostate biopsy was the major diagnostic investigation as shown on table 3; the histological type being adenocarcinoma in $100 \%$ of cases and the score gleason score 7 was most represented with 50\%. High-risk prostate cancer following D'Amico's classification was found in 49 (94\%) avec $6 \%$ of intermediare risk.

Forty-five $(86.5 \%)$ of patients had hormone therapy (chirurgical or medical) by orchidectomy or triptoreline $3.75 \mathrm{mg}$ by month and bicalutamide 50 mg by day, while 2 (3.84\%) patients underwent radical prostatectomyas shown in table 4. Docetaxel by week during 5 weeks was used for chemotherapy.

Table 1. Distribution of patients according to the hospital of management

\begin{tabular}{|l|l|l|}
\hline Hospital & Number & Percentage \\
\hline Point G & $\mathbf{1 8}$ & $\mathbf{3 4 , 6}$ \\
\hline Gabriel Touré & 12 & 23,7 \\
\hline Luxembourg & 17 & 32,7 \\
\hline Kati & 5 & 9,6 \\
\hline Total & $\mathbf{5 2}$ & $\mathbf{1 0 0}$ \\
\hline
\end{tabular}




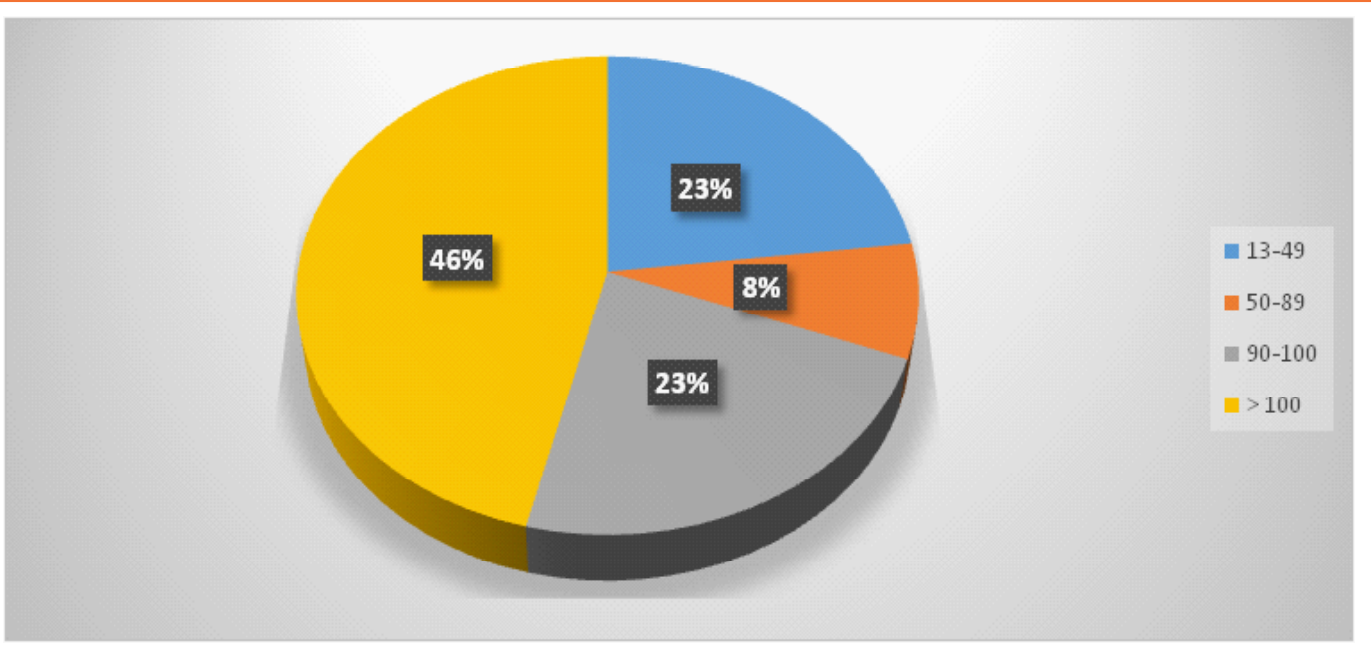

Figure 1. Distribution of patients according to the PSA level $(\mathrm{ng} / \mathrm{ml})$

Table 2. Distribution of patients according to the reason of consultation

\begin{tabular}{|l|l|l|}
\hline Reason & Number & Percentage \\
\hline Hight level PSA & $\mathbf{1 8}$ & $\mathbf{3 4 , 6 1}$ \\
\hline Pollakiuria & 12 & 23.07 \\
\hline Dysuria & 8 & 15,4 \\
\hline Erectil Dysfonction & 5 & 9,61 \\
\hline Authers reason & 9 & 17,30 \\
\hline Total & $\mathbf{5 2}$ & $\mathbf{1 0 0}$ \\
\hline
\end{tabular}

Table 3. Distribution of patients according to the type of surgical specimen sent for histopathology.

\begin{tabular}{|l|l|l|}
\hline Type of surgical specimen & Number & Percentage \\
\hline Biopsy Specimen & $\mathbf{3 4}$ & $\mathbf{6 5 , 4}$ \\
\hline Adenomectomy specimen & 10 & 19,2 \\
\hline Chips from TURP & 8 & 15,4 \\
\hline Total & $\mathbf{5 2}$ & $\mathbf{1 0 0}$ \\
\hline
\end{tabular}

Table 4. Distribution of patients according to the proposed treatment

\begin{tabular}{|l|l|l|}
\hline Treatment & Number & Percentage \\
\hline Radical prostatectomy & 2 & 3,8 \\
\hline Hormone therapy & $\mathbf{4 5}$ & $\mathbf{8 6 , 5}$ \\
\hline Chemotherapy & 3 & 5,8 \\
\hline Radiotherapy & 1 & 1,9 \\
\hline Hormonoradiotherapy & 1 & 1,9 \\
\hline Total & $\mathbf{5 2}$ & $\mathbf{1 0 0}$ \\
\hline
\end{tabular}

\section{Discussion}

Prostate cancer is generally asymptomatic when localised; however, clinical mainfestations tend to occur in metastatic disease ${ }^{4}$.

The mean age of our patients was 71 years with a range of 57 to 85 years. Our results are similar to those of Soulie M, who reported that majority of his patients (ie 421 representing $2.15 \%$ were within the age range of 70-74 years. This age range corresponds to the mean age at diagnosis reported by many authors to be between 71 and 72 years ${ }^{5}$. 
In our series, the presentation of prostate cancer was mostly an elevated PSA during a routine screening procedure by collegue in $34.61 \%$ followed by lower urinary tract symptoms suggesting advanced disease. The predominance of lower urinary tract symptoms has been published by many African authors ${ }^{2,3,6}$. Prostatic symptoms represented $49,6 \%$ in senegal. Pollakiuria and dysuria was the prostatic symptoms in our study.

Less than the majority of our patients had PSA $>100$ $\mathrm{ng} / \mathrm{ml}$, ie $46.15 \%$. Such elevated levels of PSA would explain advanced or metastatic disease. In fact, it has been established that prostate cancer is locally advanced in $80 \%$ of cases when PSA is $>50 \mathrm{ng} / \mathrm{ml}^{7}$. Niang et al found that $88.23 \%$ of patients had PSA $>50 \mathrm{ng} / \mathrm{ml}$. Several studies have revealed delayed diagnosis of prostate cancer in African countries following PSA of $>20 \mathrm{ng} / \mathrm{ml}$ thus high-risk of D'Amico by poor accessibility of urology services. ${ }^{8,9,10}$.

This strong correlation between PSA level and disease extent made us to retain a diagnosis of advanced prostate cancer by poor accessibilityand the indication for hormone therapy in $86.5 \%$ of patients. Financial constraints could probably explain the frequent use of surgical castration, and also the fact that medical castration is not reimbursed in Mali. In this series, as in that of Niang et al in Senegal, surgical castration (subcapsular orchidectomy) was mostly performed ${ }^{6}$. Thus, for Bayoumi et al.,11 surgical castration offers the cheapest cost of androgen suppression covering a long period of treatment and offers the best quality of life.

Also, the VACURD study reported by Byar ${ }^{12}$ supported the clinical efficacy of surgical castration where it was more susceptible to reduce bone pain and improve on the general condition of the patient with advanced disease compared to placebo. Today, radical prostatectomy is considered the gold standard treatment for localised prostate cancer $^{13}$. In six months, it was performed on 2 of our patients at the Luxembourg UTH against 49 in Senegal over a period of six and a half years. These low numbers of radical prostatectomies performed could be explained by the difficulty in selection of eligible patients, who are usually seen late. Also, the high morbidity related to the surgical procedure tendsto restrict patients from giving consent and some surgeons are likely to abstain.
More than $85 \%$ of our patients were seen at advanced stage and high-risk of D'Amico classification, and very few were eligible for radical prostatectomy contrary to the situation in many developed countries where this procedure is routinely performed ${ }^{14-15}$.

As surgical approach, we performed retropubic radical prostatectomy on our patients. Like Soulie et al., we preferred the retropubic approach although certain authors advocate for the transperineal approach ${ }^{17}$. From oncological and functional perspectives, no significant difference has been found between the two approaches $^{\mathbf{1 8}}$.

\section{ConClusion}

Prostate cancer has often been diagnosed at advancedstage in our multicentre study making curative treatment unlikely. Efforts for screening and the practice of radical prostatectomy should be supported and encouraged to reduce the morbidity and mortality related to this common cancer in men.

\section{REFERENCES}

[1] McNeal JE The zonal anatomy of the prostate. Prostate 1981;2:35-49

[2] Osegbe DN. Prostate cancer in Nigerians: facts and nonfacts. J Urol 1997;157:1340-3.

[3] Gueye SM, Jalloh M, Labou I, Niang L, Kane R, Ndoye M. Profil clinique du cancer de la prostate au Sénégal. Afr J Urol 2004;10:203-7.

[4] Cussenot O, Teillac P. Cancer de la prostate. 127 Paris: Path Sciences; 1999, 616.

[5] Soulié M. Epidémiologie du cancer de la prostate. Prog Urol $2003 ; 13: 1261$

[6] Niang L, Ndoye M, Ouattara A, Jalloh M, Labou M, Thiam I, Kouka SC, Diaw JJ, Gueye SM. Cancer de la prostate : quelle prise en charge au Sénégal ?.Prog Urol 2013 23, 36-41

[7] Paule B, Cicco A. Les biphosphonates dans le traitement des métastases osseuses du cancer de la prostate. Prog Urol 2001;11:1205-12.

[8] Amégbor K, Yao Seddoh T, Tengué K, B. SongneGnamkoulamba, G. Napo-Koura, K. Jameset al. Épidémiologie et histopronostic du cancer de la prostate au Togo:à propos de 202 cas diagnostiqués au laboratoire d'anatomie 
pathologique du CHU Tokoin de Lomé. Prog Urol 2009;19: 112-5.

[9] Ammani A, Janane A, Chafiki J, Sossa J, El Harrech Y, Moufid Ket al. Profil épidémiologique du cancer de la prostate dans le service d'urologie de l'hôpital Mohammed V de Rabat. J Maroc Urol 2007;5:11-14.

[10] Nwofor AM, Oranusi CK. Cancer of the prostate: experience at Nnewi, Southeast Nigeria. Niger J Clin Pract 2004;7:65-8.

[11] Bayoumi AM, Brown AD, Garber AM. Costeffectiveness of androgen suppression therapies in advanced prostate cancer. J Natl Cancer Inst 2000;92:1731-39.

[12] Byar DP.The Veterans Administration Cooperative Urological Research Group's studies of the cancer of the prostate. Cancer 1973;32:1126-38.

[13] Rozet F, Hennequin C, Beauval J.B, Beuzeboc P, Cormier L, Fromont-Hankard Get al. Recommandations francaises du Comité de Cancérologie de l'AFU pour le cancer de la prostate - actualisation 2018-2020: cancer de la prostate. Prog Urol, 2018, 12,28,S79, suppl. $12 \mathrm{~S}$.
[14] Guillonneau B, Cathelineau X, Cour F, Veillon B, Vallancien G. Actualisation de la morbidité de la prostatectomie radicale rétropubienne: analyse rétrospective de 100 interventions consécutives pendant la période 1996-1997. Prog Urol 1999;9:662-7.

[15] Carlsson S, Adolfsson J, Bratt O, Johansson J.E, Ahlstrand C, Holmberg E et al. Nationwide populationbased study on 30-day mortality after radical prostatectomy in Sweden. Scand J Urol Nephrol 2009;43:350-6.

[16] Soulié M, Grosclaude P, Villers A, Menegoz F, Schaffer P, Mace-Lesec'H J et al. Variations dans la pratique de la prostatectomie radicale en France. Prog Urol 2001;11:49-55.

[17] Comploj E, Palermo S, Trenti E, Martini T, Lodde $\mathrm{M}$, Mian C et al. Radical perineal prostatectomy: an outdated procedure? Int J Surg 2011;9(5): 400-403.

[18] May M, Dorst M, May J, Hoschke B, Fahlenkamp $\mathrm{D}$, Vogler $\mathrm{H}$ et al. Radical retropubic vs. radical perineal prostatectomy: a comparison of relative benefits in four urban hospitals. Urol Nurs2007;27:519-26.

Citation: Alkadri Diarra, Fousseini Sissoko, Mahamat Ali, et al. Multicentre Management of Prostate Cancer in Mali. Archives of Urology. 2020; 3(1): 05-09.

Copyright: (C) 2020 Alkadri Diarra, Fousseini Sissoko, Mahamat Ali, et al. This is an open access article distributed under the Creative Commons Attribution License, which permits unrestricted use, distribution, and reproduction in any medium, provided the original work is properly cited. 